\title{
The development of bioenergy technology in China
}

\author{
C.Z. Wu, X.L. Yin*, Z.H. Yuan, Z.Q. Zhou, X.S. Zhuang \\ The Renewable Energy and Gas Hydrate Key Laboratory of CAS, Guangzhou Institute of Energy Conversion, Chinese Academy of Sciences, 2 Nengyuan Road, Tianhe District,
} Guangzhou 510640, PR China

\section{A R T I C L E I N F O}

\section{Article history:}

Received 11 June 2007

Received in revised form 13 June 2008

Accepted 4 April 2009

Available online 26 May 2009

\section{Keywords:}

Bioenergy

Development

China

\begin{abstract}
A B S T R A C T
Among renewable energy resources, bioenergy is one of the fastest growth energy alternatives with tremendous potential in China. The thermal, physical, and biological processes of conversion of biomass yield a number of products and can be obtained as gases, liquids, solid fuels, and electricity as well as a variety of chemicals. Various bioenergy technologies that have been developed are at the fundamental research, demonstration, and commercialization stages. This review concentrates on the processes that are attracting the most attention in China.

This paper presents the important roles bioenergy plays in China. Firstly, the application status of bioenergy technologies are introduced, including biogas, fuel ethanol, biodiesel, and power generation at the commercialization stage. Then, the current research progresses are analyzed of ethanol derived from lignocellulose, sweet sorghum and cassava, biodiesel from jatropha, biomass briquetting, synthesized fuels and pyrolysis technologies at the fundamental research and demonstration stages. Finally, it is concluded that the key areas for developing bioenergy for the future are the exploitation of new biomass resources and R\&D in biofuels from non-food biomass resources, as well as the development of commercialization methods suitable for developing countries.
\end{abstract}

(c) 2009 Elsevier Ltd. All rights reserved.

\section{Introduction}

Biomass offers environmental advantages over fossil fuels as it is a renewable energy source with low sulphur and nitrogen content and is $\mathrm{CO}_{2}$-neutral over its production and utilization cycles. Nowadays, biomass has become the fourth largest energy source in the world, accounting for $14 \%$ of entire world's energy supply [1]. However, the energy in biomass is less concentrated than the energy in fossil fuels; technologies of converting biomass into useful bioenergy are required to make the energy competitive with coal, oil, and natural gas. A number of products can be obtained as gases, liquids and solid fuels, and electricity as well as a variety of chemicals via thermal, physical, and biological conversion processes of biomass. R\&D in bioenergy technologies has attracted considerable attention globally.

With the rapid economic growth witnessed in the last few decades, China is currently the second largest energy consumer in the world. The heavy dependence on imported petroleum is critical to China's energy security, and its coal dominant energy structure causes serious environmental problems. China's government has recognized the importance of developing bioenergy, as it possesses

\footnotetext{
* Corresponding author. Tel.: +86 20 87057731; fax: +86 2087057737 .

E-mail address: xlyin@ms.giec.ac.cn (X.L. Yin).
}

the potential to alleviate environmental pollution, slow down global warming, and reduce the country's dependence on scarce fossil fuels. Various technologies have been developed and are at the fundamental research, demonstration, and commercialization stages; this review concentrates on the developments of bioenergy that are attracting the most attention in China.

\section{The application status of bioenergy in commercialization stage}

\subsection{The roles of bioenergy in China}

Biomass is a widely available energy resource in China; its total quantity, including the portion that peasant households in rural areas consume directly, is next only to the amount of coal. The development of bioenergy is an important measure to improve energy structure, safeguard energy security, protect the environment, and realize the sustainable development of rural economy. The applications of bioenergy technology have been playing important roles in China's energy market.

As an important step to promote the development and utilization of renewable energy, China government issued 'The Law of Renewable Energy' in 2005, and it became effective on January 1st, 2006; it was followed in 2007 by the 'Medium and Long-term Development Program for Renewable Energy', in which 
industrialization of biomass electricity, biogas, biomass briquettes, and biomass liquid fuels was emphasized. The announcement of the program will be the driving force to develop bioenergy technologies. The production targets for biogas, bio-power, briquettes, ethanol, and biodiesel estimated in the program are partly shown in Table 1. Various bioenergy technologies have been developed but only a few of them have currently entered the commercial application phase. This section summarizes the application status of biogas, fuel ethanol, biodiesel, and power generation technologies.

\subsection{Application of biogas technology}

China is a world leader in the development of anaerobic digestion for the production of biogas. Starting with the introduction of household size biogas digesters in the early 1950s, biogas technology has been widely adopted to supply fuels for lighting and cooking in peasant households [2]. By the end of 2005, the number of household biogas digesters aggregated to more than 17 million, generating 8 billion $\mathrm{m}^{3}$ of biogas annually. The anaerobic digestion technology that is used to treat industrial organic wastewater and animal wastes from large-scale intensive livestock operation has also been developed over the past few decades. By the end of 2005, 3356 middle- to large-scale biogas projects had been established in thousands of livestock farms spread across the country [3]. However, the production efficiency of these projects needs further improvement.

China's economy continues to grow at a fast pace, accompanied by growth of organic wastes. Consequently, there is a ready market for the biogas technologies that can reduce pollution and produce energy. For example, for every ton of grain alcohol produced, about $500 \mathrm{~kg}$ of the organic contents remain in the wastewater. If $80 \%$ of the wastewater from the nation's distilleries is used for anaerobic digestion, about 900 million $\mathrm{m}^{3}$ of biogas can be produced. Half of all industrial organic wastewater generated can produce 25 billion $\mathrm{m}^{3}$ of biogas, which is almost equal to the total production of natural gas in China [4].

The sources for biogas production are principally a wide range of organic materials, while, crop residue can be a source of biogas production by fermentation. Related research has currently made substantial progress, which will improve the feedstock adaptability of biogas technology and extend its range of applications.

\subsection{Application of fuel ethanol technology}

In recent years, the fuel ethanol industry has grown rapidly, inspired by the renewable energy concerns, new fuel ethanol standards, and government incentives. Fuel ethanol can substitute for gasoline or be blended with conventional gasoline to supply transportation fuels. In China, large-scale application of fuel ethanol started in 1999 with the establishment of four selected fuel ethanol-manufacturing enterprises located in the Jilin, Heilongjiang, Henan, and Anhui Provinces, followed by the issue of two national standards for fuel ethanol in 2001 and 2004, respectively. At present, 27 cities distribute ethanol in nine different provinces; it

\section{Table 1}

Bioenergy production targets in the medium and long-term development programs for renewable energy.

\begin{tabular}{lllrrl}
\hline Technology & Unit & 2005 & 2010 & 2020 & Remarks \\
\hline Biogas & Billion $\mathrm{m}^{3}$ & 8.0 & 19.0 & 44.0 & Including biogas projects \\
Power & Million $\mathrm{kW}$ & 2.0 & 5.5 & 30.0 & \\
Briquetting & Million tons/year & 0 & 1.0 & 50.0 & \\
Fuel ethanol & Million tons/year & 1.0 & 2.0 & 10.0 & Including synthesized fuel \\
Biodiesel & Million tons/year & 0.1 & 0.2 & 2.0 & \\
\hline
\end{tabular}

is blended with gasoline for use in their public transportation systems. By 2005, the four state owned fuel ethanol enterprises achieved an aggregate annual yield of 1.02 million tons using stale grain as feedstock. Although the total amount of ethanol gasoline accounts for $20 \%$ of the total gasoline consumption in China, it is still much smaller than that in the U.S. and Brazil.

China is a developing country with a population of more than 1.3 billion, and its foremost task is to keep stable provisioning. It is believed that grain-based fuel ethanol production will compete with the food production, so its feedstock cost cannot be reduced greatly. At present, developing non-food feedstock based fuel ethanol is encouraged by government, especially for the feedstock that can be cultivated in the alkaline land and wasteland; in the meanwhile increase in the scale of development of the grain-based fuel ethanol production has been prohibited indefinitely. In the long term, lignocellulose ethanol technology has to be utilized to reduce the cost of ethanol, which is the major technique requiring to be developed in China in the future.

\subsection{Application of biodiesel technology}

Currently many countries permit the use of biodiesel/diesel mixture at blending ratios varying from 5 to $100 \%$. Most of the biodiesel is produced from edible oil crops, such as rapeseed as its production is abundant in the world. Biodiesel can also be produced from waste cooking oil and animal fat generated by restaurants, fast food shops, and food processing industries. The traditional way of disposing these oily wastes is not only expensive to the trade, but also increases the burden on sewage treatment and sewer maintenance. So reusing this waste has the twin benefits of producing clean fuels and recycling waste.

In China, only a few biodiesel plants have been established, and almost all of them use waste oil as feedstock; the annual yield of biodiesel is less than 100 thousand tons. At present, biodiesel is sold to consumers who need industrial fuel oil, as it cannot be transferred to public gas stations. Unstable quality caused by the feedstock prevents popularizing biodiesel applications. A national quality standard for biodiesel production has to be formulated urgently to promote the industrialization of biodiesel.

\subsection{Application of biomass electricity}

As one of the most practical renewable technologies, biomass power generation is very important as it makes use of rural wastes. Three kinds of biomass power technologies, namely biomass gasification and power generation (BGPG), biomass direct combustion and power generation (BDCPG), and co-firing power generation technologies, have been developed. All these technologies can be employed in China to suit various conditions.

With the issue of 'The Law of Renewable Energy', a series of preferential policies related to biomass power have been announced, of which the foremost relates to the purchase price of electricity from biomass power generation as 0.25 RMB Yuan higher than that of coal fired power plants in 2005 (with flue-gasdesulfurization (FGD)) [5]. Several large-scale power companies, such as the State Grid Corporation of China (SGCC), have been attracted to enter into the biomass power market. Until the end of 2006, 39 biomass power projects with installed capacities totaling $1284 \mathrm{MW}$ had obtained construction licenses from local governments. Most of these projects employ BDCPG technology introduced from the BWE Company of Denmark. The first two power stations with the capacities of $2 \times 12 \mathrm{MW}$ and $25 \mathrm{MW}$ were established in Hebei and Shandong Province, respectively. Although BDCPC is a well-proven technology in European countries, its techno-economic feasibility in these two stations has not 
been proven owing to the main problems of unstable biomass supply and alkali metal corrosion. It is known that supportive policies and a modern approach to agriculture are vital for commercializing BDCPG, which is a large-scale technology of the future.

The R\&D of BGPG technology started as early as the 1960s, characterized by a $60-\mathrm{kW}$ rice husk gasification and power generation system. Now, the 160 and $200 \mathrm{~kW}$ capacity systems are those that are mainly adopted and there are dozens of these small rice husk gasifier-power generator sets in use [6]. In 1998, a 1-MW circulating fluidized bed BGPG system was developed by Guangzhou Institute of Energy Conversion (GIEC), Chinese Academy of Sciences (CAS); however, it was limited by its low peak generating efficiency of $18 \%$. As such, the 1-MW system can only be used as captive supply power plants by rice mills and timber mills with cheap biomass resources [7]. To promote market competitiveness, a biomass integrated gasification combined cycle (BIGCC) demonstration plant with designed power output of 5.5 MW was constructed in Jiangsu Province in 2005. This plant was commissioned for trial production and the total efficiency it attained was 26-28\% with unit investment of $1200 \mathrm{USD} / \mathrm{kW}$ [8].

Aiming at the demand of biomass electricity market, serial products with the capacities ranging from 400 to $10,000 \mathrm{~kW}$ had been developed successfully, which laid the foundation for the application of BGPG technology. Since 2000, the technology has been standardized in China and several Southeast Asian countries with total installed capacity of $40 \mathrm{MW}$. At present, BGPG technology is the most widely used technology in the world for its obvious economic and environmental benefits. On analyzing its present utilization status, it is found that while BGPG technology has sufficient flexibility a series of technical problems remain to be solved.

\section{Research progress of important bioenergy technologies}

Although each type of bioenergy technology has its development space, non-food biomass-based technologies should be pursued in future, as crop residue will be the dominating biomass resource in China for a long time to come. In this section, the current research progresses are analyzed of ethanol derived from lignocellulose, sweet sorghum and cassava, biodiesel from jatropha, biomass briquetting, synthesized fuels and bio-oil from pyrolysis, as shown in Table 2.

\subsection{Biomass power generation technology}

In China, a total amount of 480 million tons of oil equivalent (TOE) from biomass is available annually, of which about $76 \%$ is usable for electricity generation. Crop residue accounts for $50 \%$ of the total biomass resources; however, crop residue is dispersive and greatly influenced by seasons, and hence costs of transportation and storage are two important factors that determine the technical route, generating capacity, and location of power stations. Based on a techno-economic feasibility study carried out by GIEC, it was suggested that decentralized utilization, such as middle-scale BGPG technology with a power output range of 1-10 MWe, may be more feasible than large-scale BDCPG technology, and has the potential to tap the market in China. However, the variety of biomass resources available is dispersed in different regions where the level of economic development is discrepant. Considering the usability of feedstock supply and local conditions, biomass power generation systems with different technical routes and scales may have to be developed simultaneously.

At present, small- to middle-scale BDCPG technology with higher efficiency and flexible BGPG technology are under development. For instance, 6-12 MW fluidized bed BDCPG systems developed by Zhejiang University [9] and 4-10 MW BGPG systems developed by GIEC [10]. Appropriate demonstration projects have been established but these systems still suffer from the problems of low efficiency and poor reliability of devices. Further studies are required to assess their techno-economic feasibility. On the other hand, with the development of hydrogen production from biomass and fuel cell technology, integrating biomass gasification with power generation technology appears to be the most promising technology route for producing electricity from biomass.

\subsection{Bioethanol from sweet sorghum and cassava}

Bioethanol production from grain and sugar is currently the most feasible technology to achieve mass production of biomass

Table 2

Current progress in bioenergy technology research.

\begin{tabular}{|c|c|c|c|}
\hline Technology & Development task & Up-to-date progress & Major problems \\
\hline $\begin{array}{l}\text { Biomass power } \\
\text { generation }\end{array}$ & $\begin{array}{l}\text { To develop small- to middle-scale BDCPG and } \\
\text { BGPG technologies with high generating } \\
\text { efficiency and sufficient flexibility }\end{array}$ & $\begin{array}{l}\text { 6-12 MW fluidized bed BDCPG system [9] and 4-10 MW BGPG } \\
\text { system have been investigated [10] }\end{array}$ & $\begin{array}{l}\text { Low generating efficiency and poor } \\
\text { reliability of device }\end{array}$ \\
\hline $\begin{array}{l}\text { Bioethanol from } \\
\text { sweet sorghum } \\
\text { and cassava }\end{array}$ & $\begin{array}{l}\text { To reduce production cost of bioethanol; to } \\
\text { develop low energy consumption techniques }\end{array}$ & $\begin{array}{l}5000 \text { ton/year sweet sorghum ethanol demonstration project [11]; } \\
\text { and } 400,000 \text { ton/year cassava ethanol project }\end{array}$ & Storage and pretreatment of feedstock \\
\hline $\begin{array}{l}\text { Bioethanol from } \\
\text { lignocellulose }\end{array}$ & $\begin{array}{l}\text { To develop cost-effective cellulose ethanol } \\
\text { technique and establish dispersed cellulose } \\
\text { ethanol industry }\end{array}$ & $\begin{array}{l}600 \text { ton/year dilute acid hydrolysis cellulose ethanol } \\
\text { demonstration project [12]; } 3000 \text { ton/year enzymatic hydrolysis } \\
\text { coupled with solid state fermentation ethanol from cellulose } \\
\text { demonstration project [13] }\end{array}$ & $\begin{array}{l}\text { Low conversion rate and high energy } \\
\text { consumption in production process }\end{array}$ \\
\hline $\begin{array}{l}\text { Biodiesel from } \\
\text { Jatropha }\end{array}$ & $\begin{array}{l}\text { To look for new feedstock for biodiesel } \\
\text { production }\end{array}$ & $\begin{array}{l}10,000 \text { ton/year demonstration project for Jatropha is under } \\
\text { construction in Yunnan and Guizhou Provinces }\end{array}$ & $\begin{array}{l}\text { Mass production and mechanized } \\
\text { collection of Jatropha crops; effective } \\
\text { utilization of residues }\end{array}$ \\
\hline $\begin{array}{l}\text { Biomass } \\
\text { briquetting }\end{array}$ & $\begin{array}{l}\text { To develop briquettes that can partly substitute } \\
\text { for coal }\end{array}$ & $\begin{array}{l}\text { Related research on biomass briquetting has obtained the support } \\
\text { of government }\end{array}$ & $\begin{array}{l}\text { Relatively low efficiency and serious } \\
\text { device abrasion }\end{array}$ \\
\hline $\begin{array}{l}\text { Liquid fuels from } \\
\text { biomass } \\
\text { syngas }\end{array}$ & $\begin{array}{l}\text { To develop oxygenated fuels (methanol/DME) } \\
\text { and promote their industrialization }\end{array}$ & $\begin{array}{l}100 \text { ton/year DME synthesis facility has been investigated; } \\
1000 \text { ton/year demonstration project for DME synthesis is } \\
\text { prepared for construction }\end{array}$ & $\begin{array}{l}\text { Cleaning and reforming of syngas; } \\
\text { synthesis techniques suitable for } \\
\text { small-scale; catalysts suitable for bio- } \\
\text { syngas }\end{array}$ \\
\hline $\begin{array}{l}\text { Bio-oil from } \\
\text { pyrolysis }\end{array}$ & $\begin{array}{l}\text { To produce sustainable fuels for fuel oil; to } \\
\text { produce transportation fuels and chemicals }\end{array}$ & $\begin{array}{l}2000 \text { ton/year bio-oil production plant has been built in Anhui } \\
\text { Province }\end{array}$ & $\begin{array}{l}\text { Scale-up of pyrolysis reactor; unstable } \\
\text { quality of bio-oil; effective and } \\
\text { economic upgrading and refining } \\
\text { methods }\end{array}$ \\
\hline
\end{tabular}


liquid fuels. A dramatic increase in ethanol production using the current cornstarch- and grain-based technology may not be practical in China because ethanol production will compete for the limited agricultural land needed for food and feed production.

Sweet sorghum is one of the most promising energy crops, particularly for ethanol production. It is reported that more than 125 sweet sorghum resources have been registered in China [14]. Development of sweet sorghum has been an agricultural policy option of the government and the international agencies that aim at improving agricultural land use by promoting sustainable crops and valuing semi-arid and other undeveloped lands. This strategy had been strongly advocated since the 1980s and has the support of the United Nations Food and Agricultural Organization (FAO). At present, a 5000 ton/year sweet sorghum ethanol demonstration project has been established with the support of the National HighTech Program [11].

Cassava, a perennial woody shrub with up to $32 \%$ (fresh) starch content, has attracted more and more attention recently. Cassava is an ideal feedstock for fuel ethanol production; it has two advantages over other feedstocks. First, cassava is cultivable on marginal lands where other crops, such as corn, wheat, rice and sugarcane do not grow well; second, cassava is not a staple food for the Chinese. Using cassava for ethanol production does not raise major ethical and moral issues as corn ethanol does. Of the total amount of cassava in China, $90 \%$ is distributed in the Guangdong and Guangxi Provinces. The local governments intend to promote cassava fuel ethanol as a substitute for gasoline [15]. For example, a 400,000 ton/year cassava ethanol project is under development since 2005.

Anyway, the development of fuel ethanol from sweet sorghum, cassava, or sweet potato still remains at the demonstration stage. At present, the common problems encountered by the technologies are storage and pretreatment of feedstock. In the meantime, to reduce production cost, low energy consumption technology (i.e. the increase of fermentation concentration and the decrease of fermentation time) will be developed in the future.

\subsection{Bioethanol from lignocellulose}

Taking long-term views, a potential source for low cost ethanol production are lignocellulosic materials, such as crop residue, grass, sawdust, wood chips, solid animal waste, and industrial wastes. Developing lignocellulose ethanol has been keeping an important orientation in China, like other countries. Extensive research on the conversion of lignocellulosic materials to ethanol has been carried out since the national eighth five-year plan period. Enzymatic hydrolysis and dilute acid hydrolysis of cellulose as a pretreatment method have been investigated by several universities, such as East China University of Technology, Zhejiang University, and Qinghua University. For instance, a 600 ton/year dilute acid hydrolysis cellulose ethanol demonstration system, carried out by the East China University of Technology, and a 3000 ton/year enzymatic hydrolysis coupled with solid state fermentation system established by Institute of Process Engineering, CAS, have yielded positive results $[12,13]$. Although some important technological difficulties in reducing the cost of lignocellulose ethanol have been solved, the feasibility of these systems has not been proven commercially. The major problems are the low conversion rate and higher energy consumption in the production process. The Ministry of Science and Technology of China (MOST) is mapping out new research plans to establish appropriate demonstration projects in order to tackle the key problems. Integrated utilization of the hydrolysis residue will be the research emphasis of reducing the production cost of lignocellulose ethanol.

\subsection{Biodiesel from jatropha}

Biodiesel has attracted considerable attention recently; however, the key determinant of developing biodiesel will be the availability of feedstock. As a large consumption country of edible oil, the demand for cooking oil supply should be met first. The potential for biodiesel production from the oil plants, such as rapeseed and soybean, is quite limited, and comes with higher cost of feedstock. On the other hand, the potential for biodiesel production from the restaurant waste oil is less than 2 million tons/year. Under such circumstances, securing new feedstock for biodiesel production will be the key factor for the development of biodiesel. Jatropha crops have been paid more attention recently.

Jatropha is one of the non-edible tree-based oil seeds available in China, which is mainly distributed in the Sichuan, Guizhou, and Yunnan Provinces. The oil yield of different species ranges from 30 to $60 \%$ [16]; these oil seeds have great potential for being transesterified to produce biodiesel. Jatropha grows rapidly, taking 2-3 years of crop cycle to reach maturity and generate economic yields, while it requires only minimal water and nutrients, and is able to grow on marginal, poor, or degraded land, including desert or semidesert types. Cultivation of jatropha crop has the potential to create a new agricultural industry while also providing cost-effective biodiesel feedstock. At present, the main technical problems are mass production, mechanized collection of the jatropha crops, and effective utilization of residues after producing biodiesel. Demonstration projects with capacities exceeding 10,000 tons/year are under construction in the Yunnan and Guizhou Provinces.

\subsection{Biomass briquetting}

The low energy density of biomass results in additional transportation and storage costs. In order to develop a large-scale biomass unit, it is necessary to convert biomass into high-density and high-value solid fuels, i.e. briquettes. Replacing coal by briquettes is one of the main specific development orientations prescribed by the Chinese government in recent years. The briquetting devices developed so far have not been able to meet the demand of commercial application, mainly due to the barriers of relatively low efficiency, higher energy consumption, and serious device abrasion, especially for crop residue processes. Therefore, it is necessary to increase the total efficiency of utilization and reduce the cost of production. On the other hand, the existing devices for the combustion of briquettes are all modifications of coal fired combustion devices, which are not suitable for the production of briquettes from the point of view of combustor volume and shape, as these characteristics reduce combustion efficiency and cause serious pollution problems.

Biomass briquetting technology has been under study for a long time; but some projects for the production of briquettes and combustion device have come up only recently. However, biomass briquetting technology is in its early stages. Restricted by an incomplete industry chain of technology and devices, the investment in biomass briquetting and the cost of production are too high to meet the demand of the market economically. For example, the cost of briquettes supplied in rural areas is at present about 350500 Yuan/ton.

\subsection{Synthesized fuels from biomass syngas}

Synthesized fuel derived from bio-syngas is regarded as the second generation technology for biomass liquefaction which is considered one of the most promising technologies of the future. In China the government has paid more attention to synthesized 
fuels, of which oxygenated fuels, such as methanol and DME are prominent for the following reasons: first, it is easier to achieve economies of scale in producing oxygenated fuels from bio-syngas than in producing hydrocarbon fuels (diesel and gasoline); therefore, oxygenated fuels are more suitable for the dispersed biomass resources in China. Next, DME can partly substitute LPG fuel which is extensively used in rural areas. It is expected that the replacement of LPG by DME produced from bio-syngas can result in considerable social and economic benefits in China.

Based on the 100 tons/year DME synthesis facility established by GIEC in 2005, a 1000 tons/year demonstration project had been achieved in 2008. Whether the technology can be industrialized depends on the economic viability in small-scale operation (less than 10,000 ton/year). The key technologies that should be currently pursued are the cleaning and reforming of bio-syngas, the development of suitable synthesizing techniques on small scale, and the catalytic process suitable for bio-syngas production. The mere application of the coal based synthesis techniques is inadequate to reduce to economic levels the cost of biomass-synthesized fuels.

\subsection{Bio-oil from fast pyrolysis}

Fast pyrolysis is now an accepted feasible route to renewable liquid fuels, chemicals, and derived products. In China, fast pyrolysis for the production of bio-oil has been under development since the 1990s. Various reactors and processes have been investigated on lab scale; only few of them are in the demonstration phase. For example, the University of Science and Technology of China has developed a self-heating fluidized bed reactor of capacity $120 \mathrm{~kg} / \mathrm{h}$ with bio-oil yield of $60 \mathrm{wt} \%$ and $50 \mathrm{wt} \%$ based on sawdust and crop stalk, respectively. A demonstration facility with a capacity of 2000 ton/year is under construction in the Anhui Province.

Bio-oil has significant advantages in storage and transport over gas and heat; it can substitute for fuel oil or diesel in many static applications including boilers, furnaces, engines, and turbines for electricity generation. Recently, studies have focused on upgrading bio-oil to produce transportation fuels. These studies are on lab scale and currently not economic. Although pyrolysis is still at the development stage, it has received special attention as it offers a convenient way to convert low value crop residues into liquid fuels and value-added products. Government has supported different methods for upgrading bio-oil and many projects related to pyrolysis.

\section{The key issues of bioenergy development in China}

Although various bioenergy technologies have been developed in the last few decades in China, the utilization levels of different technologies are unevenly balanced. For example, biogas has been commercially utilized; biomass electricity, biomass briquettes, fuel ethanol, and biodiesel have only entered the early stage of commercialization and require further subsidies and incentives; lignocellulose ethanol, synthesized fuels, and bio-oil technologies are at research and demonstration stages, and expected to be commercialized in 20 years. To promote the development of bioenergy, key issues to be prioritized are cultivation of new resources, development of non-food biomass-based biofuels, and exploration of commercial methods suitable for developing countries.

\subsection{Exploiting new biomass resources}

As an agricultural country, various biomass resources are attractive feedstocks that show the best near-term promise for utilization as feedstock for power and biogas generation. Waste
Table 3

Assessment of biomass resources in China (million tons of coal equivalent).

\begin{tabular}{|c|c|c|c|c|c|}
\hline & $2004 / 2005$ & 2010 & 2020 & 2030 & Remarks \\
\hline Agricultural stalk & 62 & 90 & 150 & 200 & \\
\hline Forestry residue & 70 & 80 & 104 & 133 & At an annual rate of $2.5 \%$ \\
\hline Livestock manure & 107 & 124 & 159 & 203 & At an annual rate of $2.5 \%$ \\
\hline $\begin{array}{l}\text { Industrial organic } \\
\text { waste }\end{array}$ & 35 & 41 & 52 & 66 & At an annual rate of $2.5 \%$ \\
\hline $\begin{array}{l}\text { Municipal organic } \\
\text { waste }\end{array}$ & 2.5 & 4 & 8 & 18 & At an annual rate of $8 \%$ \\
\hline Energy crop & - & 1 & 10 & 20 & $\begin{array}{l}\text { Exploitation rate of reserved } \\
\text { cultivable agricultural land and } \\
\text { vacant fields in winter stepped } \\
\text { up to } 50 \%\end{array}$ \\
\hline Energy forestry & - & 2 & 20 & 80 & $\begin{array}{l}\text { Exploitation rate of reserved } \\
\text { cultivable forestry land and } \\
\text { existing energy forestry stepped } \\
\text { up to } 50 \%\end{array}$ \\
\hline Total & 276 & 342 & 503 & 720 & \\
\hline
\end{tabular}

biomass resources are currently abundant, underutilized, and cheap, possessing utilization potential of 270 million tons of coal equivalent. However, to achieve the national goals set for bioenergy, the utilization of other biomass sources such as dedicated energy crops is required. Table 3 shows the assessment of biomass resources of the future. Taking the two together, waste biomass resources will increase gradually with the development of social economy. The total amount will touch 500 million tons of coal equivalent by 2020 , and 600 million tons by 2030. In addition, cultivating energy crops and energy forestry by utilizing various marginal lands can increase 100 million tons of coal equivalent, of which 42 million tons of coal equivalent will come from the fuel ethanol and biodiesel.

From Table 3, it can be seen that the potential of biomass resources is relatively small in comparison with the total demand of China. Enhancing stable supply of biomass is the key to the development of bioenergy. To raise the utilization rate of the waste biomass and to enlarge supply approach and capability are crucial in solving the problems. To develop new species of energy crops and enhance their productivity by means of genetic engineering are the most promising measures to be promptly instituted. It is important to cultivate new energy crops that do not compete for the limited agricultural land that is needed for food and feed production. Therefore, the availability of the cost-effective feedstock and the stable supply of biomass resources are the two key issues in the development of bioenergy.

\subsection{Developing biofuels from non-food biomass}

To develop biomass liquid fuels will be the key to utilizing biomass resources in China; at the same time, considering the characteristics of biomass resources, biofuel production should not compete with food crops for scarce arable land. Bioethanol from lignocellulose, bio-oil via pyrolysis, synthesized fuels derived from

Table 4

Economic predictions for fuel ethanol production in five years.

\begin{tabular}{lllll}
\hline No. & Feedstock and techniques & $\begin{array}{l}\text { Efficiency } \\
(\%)\end{array}$ & $\begin{array}{l}\text { Capital cost } \\
\text { (Yuan/ton) }\end{array}$ & $\begin{array}{l}\text { Production cost } \\
\text { (Yuan/ton) }\end{array}$ \\
\hline 1 & Corn & 33 & 3500 & $4000-4500$ \\
2 & Cassava (fresh) & $12-14$ & 1960 & 3500 \\
3 & Sugarcane (fresh) & 7 & 3000 & 4000 \\
4 & Cellulose/dilute acid hydrolysis & $15-25$ & 7740 & 6000 \\
5 & Cellulose/enzyme hydrolysis & $15-25$ & 9840 & 7000 \\
\hline
\end{tabular}


Table 5

Economic predictions for biodiesel production in five years.

\begin{tabular}{lllll}
\hline $\begin{array}{l}\text { Raw } \\
\text { material }\end{array}$ & $\begin{array}{l}\text { Material price } \\
\text { (Yuan/ton) }\end{array}$ & $\begin{array}{l}\text { Yield } \\
(\%)\end{array}$ & $\begin{array}{l}\text { Capital cost } \\
\text { (Yuan/ton) }\end{array}$ & $\begin{array}{l}\text { Production cost } \\
\text { (Yuan/ton) }\end{array}$ \\
\hline Rapeseed & $7500-7800$ & $90-95$ & $2300-2500$ & $8400-8700$ \\
Jatropha & $3000-5000$ & $90-93$ & $2300-2500$ & $6600-6900$ \\
Palm oil & $7200-8280$ & $90-93$ & $2300-2500$ & $8100-9180$ \\
Waste oil & $3000-3500$ & $70-80$ & $2600-2800$ & $4100-4600$ \\
\hline
\end{tabular}

bio-syngas, and biodiesel from jatropha or Chinese pistache are the promising technologies for the future. At present, the research on these technologies is underway; however, there will be a long way to go before these technologies are industrialized.

\subsection{Developing suitable commercialization mode of bioenergy industry}

The production cost is the bottleneck in the application of bioenergy. Tables 4 and 5 show the economic predictions for fuel ethanol and biodiesel production in five years. It can be seen that the economic feasibility will remain the major problem for a long time. Effective methods of reducing production cost include the reduction of feedstock cost, increase in conversion efficiency and the reduction in investment on plant and equipment. However, the most important factor that should be considered in China in the bioenergy industry is how to meet the development demands of the rural economy, such as providing new jobs and increasing agricultural output. It is also important to develop bioenergy technologies and products particularly suitable for rural areas, and to develop bioenergy commercialization modes suitable for developing countries. Effective methods to improve the integration of the benefits of the bioenergy industrialization from the development of the widely dispersed biomass energy systems, smallscale energy farms, and energy forestry centers need to be explored.

\section{Conclusions}

Bioenergy is expected to become one of the key energy resources to cope with global warming and exhaustion of fossil fuel resources. Although various bioenergy technologies have been developed in the last few decades in China, the utilization levels of different technologies are unevenly balanced. Biogas has been commercially applied; biomass electricity, biomass briquette, fuel ethanol, and biodiesel have entered the early stage of commercialization; lignocellulose ethanol, synthesized fuels, and bio-oil technologies are in the research and demonstration stages. It is concluded that the key issues of bioenergy development in the future are the exploitation of new biomass resources, the R\&D of biofuels from non-food biomass resources, and the development of suitable commercialization method for developing countries.
All biofuels have to compete with fossil fuels. No company is going to invest in ventures that are guaranteed to lose money, regardless of the environmental benefits that may accrue. Economic feasibility of bioenergy is related to various factors, such as incentive policies, economies of scale, technical feasibility, costeffective feedstock, local resource conditions, and suitable commercialization methods. Promoting new bioenergy technologies will provide China additional environmental benefits and take it a positive step forward to a future that ensures sustainable energy. More research on bioenergy has to be conducted to meet the demands of national development targets.

\section{Acknowledgment}

The authors acknowledge the support extended to this work by the National Development and Reform Commission.

\section{References}

[1] WEC. Guide for the development of new renewable energy in the future Beijing: World Energy Council; 1998 [Chinese version].

[2] Leung YC, Yin XL. Research and development of bio-energy in China. In: Proceedings of the 2001 international conference on the effect of acid deposition on cultural properties and materials in East Asia. Korea; 30-31 August 2001. p. 57-65.

[3] National Bureau of Statistics of China, editor. China statistical yearbook. Beijing: Statistics Press of China; 2005 [in Chinese].

[4] Li J, Wan YH, Ohi JM. Renewable energy development in China: resource assessment, technology status, and Greenhouse gas mitigation potential Applied Energy 1997;56:381-94.

[5] National Development and Reform Commission, China. Renewable energy generated electrical pricing and fee sharing management rules. See also: $<$ http:/| www.gov.cn/ztzl/2006-01/20/content_165910.htm>; 2006 [in Chinese].

[6] Wu CZ, Huang H, Zheng SP, Yin XL. An economic analysis of biomass gasification and power generation in China. Bioresource Technology 2002;83:65-70.

[7] Yin XL, Wu CZ, Zheng SP, Chen Y. Design and operation of a CFB gasification \& power generation system for rice husk. Biomass and Bioenergy 2002;23:181-7.

[8] Wu CZ, Yin XL, Chen P, Ma LL. A 5.5 MW $\mathrm{MW}_{\mathrm{e}}$ biomass demonstration power plant via gasification integrated combined cycle. In: The third international green energy conference. Västerås, Sweden; 18-20 June 2007.

[9] Luo Z, Yu C, Wang Q. Research and development of fluidized bed stalk combustion technology. Zhejiang Energy 2006;6:42-4 [in Chinese].

[10] < http://www.resourcesaver.com/file/toolmanager/O105UF1985.pdf > [in Chinese].

[11] < http://www.863.org.cn/863_105/production/production_engergy/20061228 $0002 . \mathrm{html}>$ [in Chinese].

[12] < http://www.863.org.cn/863_105/production/production_engergy/20061228 0001.html $>$ [in Chinese].

[13] < http://www.pmec.net/ynzx/fzdt/20830.htm > [in Chinese].

[14] Gnansounou E, Dauriat A, Wyman CE. Refining sweet sorghum to ethanol and sugar: economic trade-offs in the context of North China. Bioresource Technology 2005;96:985-1002.

[15] Dai D, Hu Z, Pu G, Li H, Wang C. Energy efficiency and potentials of cassava fuel ethanol in Guangxi region of China. Energy Conversion and Management 2006;47:1686-99.

[16] Li H, Chen L, Tang L, Chen F. Analysis on physical and chemical characteristics of Jatropha seed oil in south-west regions of China. Chinese Journal of Applied and Environmental Biology 2006;12(5):643-6 [in Chinese]. 